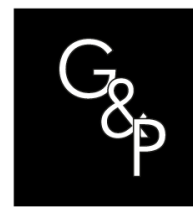

\title{
Economic, social and environmental aspects of the sustainability of a construction waste recycling plant
}

\author{
Aspectos econômico, social e ambiental da sustentabilidade de uma \\ usina de reciclagem de resíduos de construção civil
}

\author{
Eduardo Madeira Brum ${ }^{1}$ (D), Adalberto Pandolfo ${ }^{1}$ (D), Ritielli Berticelli ${ }^{1}$ (D), Rosa Maria Locatelli Kalil ${ }^{1}$ (D), \\ Pamela Bia Pasquali ${ }^{2}$ (D)
'Universidade de Passo Fundo - UPF, College of Engineering and Architecture, Postgraduate Studies Program in Civil and Environmental Engineering - PPGENG, Passo Fundo, RS, Brasil. E-mail: edumabrum@gmail.com; adalbertopandolfo@hotmail.com; ritiberticelli@yahoo.com.br; kalil@upf.br
${ }^{2}$ Universidade de Passo Fundo - UPF, Environmental Engineering Graduation Program, College of Engineering and Architecture, Passo Fundo, RS, Brasil. E-mail: pbp.pasquali@hotmail.com

How to cite: Brum, E. M., Pandolfo, A., Berticelli, R., Kalil, R. M. L. \& Pasquali, P. B. (2021). Economic, social and environmental aspects of the sustainability of a construction waste recycling plant. Gestão \& Produção, 28(3), e5120. https://doi.org/10.1590/1806-9649-2021v28e5120

\begin{abstract}
The civil construction industry has great prominence in the national economy, however, the sector is responsible for generating a large amount of Construction Waste (CW). The CW recycling plants present technological solutions that aim to minimize the environmental impact caused by the inadequate disposal of the $\mathrm{CW}$, and that the generated material is no longer a problem and becomes a sustainable outlet for the scarcity of natural resources. This article analysed the economic, social and environmental aspects of an CW recycling plant, situated in Passo Fundo I RS. As a result, the quantification and classification of waste sent to the CW recycling plant was obtained from March to December 2016. An economic evaluation of the plant was carried out based on the comparison of the economic decision criteria between the Minimum Acceptable Rate of Return (MARR) and Internal Rate of Return (IRR). Subsequently, social aspects were evaluated, such as the profiles of employees, their salaries and issues related to health and safety, education and training. When assessing the environmental aspect of the $\mathrm{CW}$ recycling plant, the composition, the separation process employed and the way in which these residues were used were determined. The conclusions demonstrated that the company is economically viable since the IRR was higher than the MARR. In the social assessment, the employment opportunity for different genres stands out and regarding the environmental question, the ability to reuse civil construction waste in $97.98 \%$ of the material received.
\end{abstract}

Keywords: Construction waste; Construction waste recycling plant; Economic, social and environmental analysis.

Resumo: A indústria da construção civil tem grande destaque na economia nacional, entretanto, o setor é responsável por gerar uma grande quantidade de Resíduos de Construção Civil (RCC). As usinas de reciclagem de RCC apresentam soluções tecnológicas que visam minimizar o impacto ambiental causado pela disposição inadequada dos RCC, sendo que o material gerado deixa de ser um problema e passa a ser uma saída sustentável para escassez dos recursos naturais. Este artigo analisou os aspectos econômico, social e ambiental de uma usina de reciclagem de RCC,

Recebido em: Jan. 20, 2019 - Aceito em Nov. 28, 2019

Financial: None . 
instalada em Passo Fundo/RS. Como resultados obteve-se a quantificação e classificação dos resíduos enviados à usina de reciclagem de RCC no período de março a dezembro de 2016. Realizou-se a avaliação econômica da usina com base na comparação dos critérios econômicos de decisão entre a Taxa Mínima de Atratividade (TMA) e Taxa Interna de Retorno (TIR). Posteriormente foram avaliados os aspectos sociais, como os perfis dos colaboradores, seus salários e questões relacionadas à saúde e segurança, educação e treinamento. $\mathrm{Na}$ avaliação do aspecto ambiental da usina de reciclagem de RCC, determinou-se a composição, o processo de separação empregado e a forma de utilização destes resíduos. As conclusões demonstraram que a empresa é viável economicamente visto que a TIR foi maior que a TMA. Na avaliação social destaca-se a oportunidade de emprego para gêneros distintos e na questão ambiental a capacidade de reaproveitar os resíduos de construção civil em $97,98 \%$ do material recebido.

Palavras-chave: Resíduos de construção civil; Usina de reciclagem de resíduos de construção civil; Avaliação econômica, social e ambiental.

\section{Introduction}

Civil construction is one of the sectors with the greatest growth and generation of jobs and income, ensuring economic and social development (Moraes \& Henkes, 2013; Paschoalin \& Duarte, 2015). However, the waste of materials in construction works, the lack of recycling procedures for these materials in the construction work itself and the reforms and demolitions generate a large amount of Civil Construction Waste (CW).

The destination of these $\mathrm{CW}$ in unlicensed locations can generate several environmental impacts which affect the population and the environment. The impacts caused are not restricted only to the environment, but also to the economic range, since the accentuated disposal of this material results in high transport costs for its final disposal (Bohne et al., 2009). Thus, the implantation of CW recycling plants is justified, in order to reduce the environmental impact caused by the generation of these residues and promoting their recovery, making it a sustainable alternative.

Zanutto (2012) mentions that although the civil construction industry has great prominence in the national economy, the sector is also a major consumer of resources. The $\mathrm{CW}$ recycling plants present technological solutions that aim to minimize the environmental impact caused by the inadequate disposal of the $\mathrm{CW}$, and that the generated material is no longer a problem and becomes a sustainable outlet for the scarcity of natural resources (Barbosa, 2012). For John (2000) the recycling of waste is one of the most important variables, since the generation of waste is often inevitable and the improvement with reinsertion of recyclable materials in the production cycle makes the economy more sustainable.

There are countless applications for the use of recycled aggregates, such as Almeida et al. (2018) analyzed the feasibility of using recycled aggregate as granular material applied as a base / sub-base for urban pavement structures. The authors concluded that the $\mathrm{CW}$ material can be transformed into a recycled aggregate with technological conditions to use in the execution of urban pavement layers.

It is estimated that the civil construction sector consumes around $50 \%$ of the available natural resources, in addition to generating a high volume of waste. Approximately 40 to $60 \%$ of the solid waste produced daily in cities comes from construction works in general (Silva \& Teixeira Fernandes, 2012).

In the United States, the rubble originated comes from: $48 \%$ from demolitions, $44 \%$ from renovations and only $8 \%$ from new constructions. It is estimated that $20 \%$ to $30 \%$ of the total waste is reused in reprocessing and recycling operations (Baptista \& Romanel, 2013). 
In Brazil, in 2005, it was estimated that the origin of the CW in the municipalities was subdivided as follows: new residences were responsible for $20 \%$, new buildings, with an area above $300 \mathrm{~m}^{2}$, generated $21 \%$ and renovations, extensions and demolitions were responsible for $59 \%$ of the CW (Pinto \& Gonzáles, 2005).

With the acceleration of the urbanization process and the stabilization of the economy, in recent years, a high volume of construction and demolition waste has been generated, reflecting on a problem in the structure of the municipalities, which are not prepared to manage this waste (Halmeman et al., 2009).

Regarding the legislation, resolution No. 307 of the National Environment Council Conselho Nacional do Meio Ambiente -(CONAMA) is dated from 2002 and deals with quantifying and classifying civil construction waste (Brasil, 2002). In 2010 Law No. 12,305 was approved, which deals with the National Solid Waste Policy (Brasil, 2010), which determined that municipalities have to study, legislate and comply with the National Solid Waste Policy Law. All waste generated in the national territory, including the CW, must be handled properly, following the hierarchy of minimization in the generation, reuse, recycling and treatment of solid waste, as well as an environmentally appropriate final disposal of the waste.

In many municipalities, concerns about $\mathrm{CW}$ management are increasing. In the city of Passo Fundo / RS, the Municipal Law No. 4,969 was approved in 2013, which deals with the Municipal Solid Waste Policy, which refers to, among other matters, the destination of construction waste by construction companies working in the city (Passo Fundo, 2013).

In Brazil, in 2016, there were 310 construction waste recycling plants, $74 \%$ of which are in operation, $7 \%$ of the plants are inactive, $9 \%$ are being implemented, $8 \%$ are under testing, $1 \%$ in project and $1 \%$ permanently inactive (Miranda et al., 2016). In the same survey, 105 plants were analyzed, 93 of which responded to current production and its maximum production capacities. The results indicate that these 93 plants together produce an average of $431,500 \mathrm{~m}^{3}$ of recycled aggregates per month, with the maximum installed capacity being 958,000 $\mathrm{m}^{3}$ per month (Miranda et al., 2016). Checking the low index of aggregate produced according to the maximum operating capacity, it is necessary to potentialize the sector, emphasizing how the plants can contribute to sustainability in a more comprehensive way.

This research aims to verify the economic, social and environmental aspects of a construction waste plant situated in the city of Passo Fundo / RS. To this end, the quantification and classification of the $\mathrm{CW}$ sent to the CW Plant was made, determining the amount of materials that are not extracted from nature when recycling, and presenting the amount of materials received by the plant and that cannot be recycled.

\section{Research method}

The Recycling Plant started its operation in 2015, in Passo Fundo / RS. It is the first and only licensed CW plant in the municipality and has an area of $13,850 \mathrm{~m}^{2}$. Passo Fundo is a municipality in the state of Rio Grande do Sul, $293 \mathrm{~km}$ from Porto Alegre, the province capital. It has an area of $783.42 \mathrm{~km}^{2}$ and a population of approximately 196,739 inhabitants, being at an altitude of approximately $687 \mathrm{~m}$ (Passo Fundo, 2016).

According to the Central Company Register (CEMPRE), base year 2012, Passo Fundo / RS performed as the 109th municipality that generates the most jobs in Brazil and the eighth in Rio Grande do Sul, with civil construction being the sector responsible for the largest number of hires, with an increase of $24 \%$ in relation to 2011 (Passo Fundo, 2016). 
To meet the aim of this work, the characterization of the object of study was carried out and the research methods, data collection, and treatment of the collected information were presented. The steps were defined according to the flowchart in Figure 1.

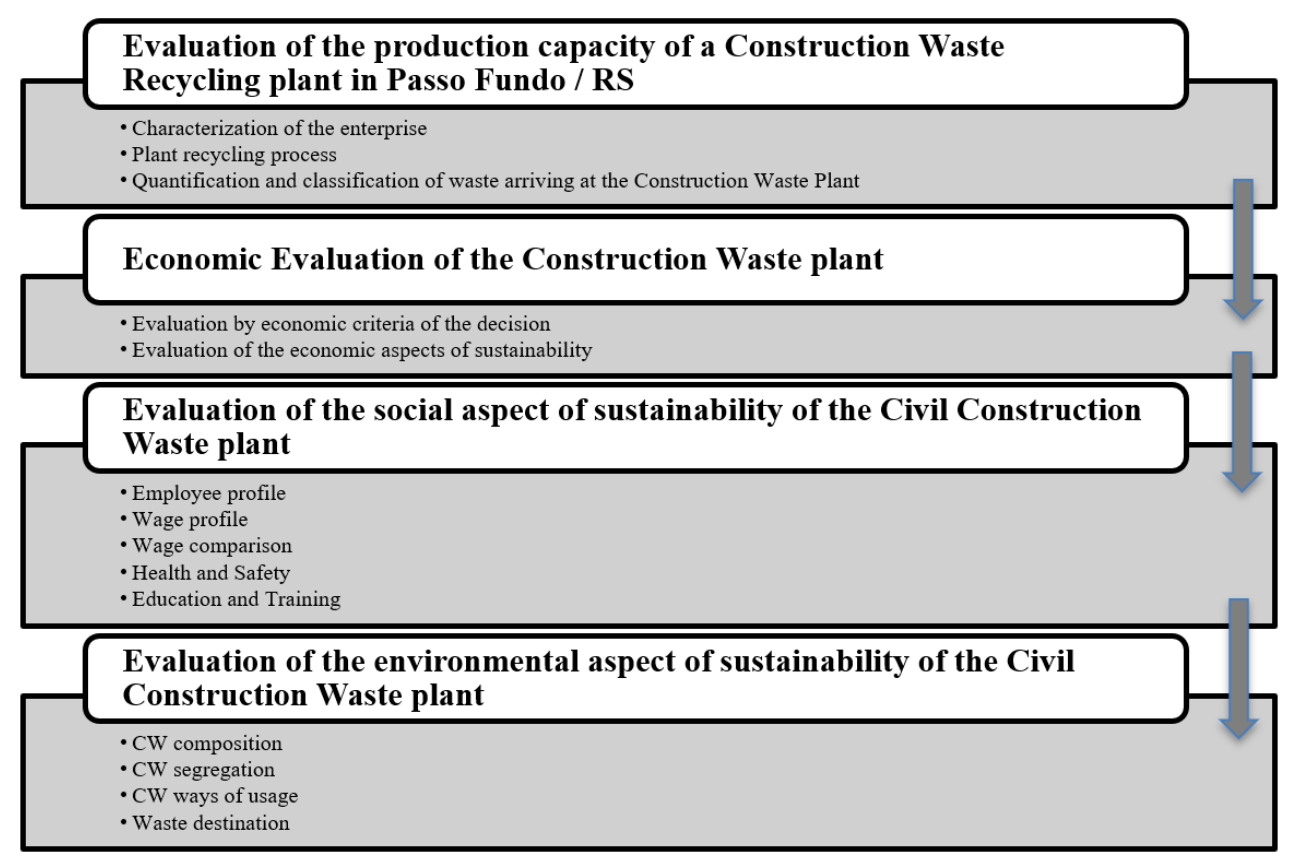

Figure 1. Methodological framework for research development. Fonte: Autores (2017).

The following is a description of the procedures adopted for the development of the research, according to the structure of the flowchart presented above.

\section{Stage 1 Evaluation of the production capacity of a construction waste recycling plant in Passo Fundo / RS}

\section{Phase 1.1 Characterization of the enterprise}

In this phase, the characteristics of the enterprise were presented, such as location, plant, labour and existing equipment. The characterization was carried out through a survey during a technical visit to the Civil Construction Waste plant and a bibliographic review.

\section{Phase 1.2 Plant recycling process}

To characterize the recycling process, an initial technical visit to the company was made, with an interview with the entrepreneur who explained the operation of the company and provided the necessary information for this research.

The first operation process of the CW plant is the receipt of waste. Continuing, the waste separation process was verified, which includes the entire process for the Civil Construction Waste processing. 
The next part in this phase is the processing of recycled aggregates, that is, the final product of production. It was verified with the entrepreneur where these recycled materials are stored, as well as what is done with them after processing.

After getting to know the receiving processes, separating the CWs and their final product, information was sought about the physical arrangement of the company, and the process of the plant as a whole was verified.

Subsequently, data related to employees were verified, such as:

- Whether current employees attend to the operation of the recycling plant;

- Whether the labor is qualified;

- How training and qualification of employees are carried out before they start working.

Phase 1.3 Quantification and classification of waste arriving at the Construction Waste Plant

In this phase, the quantification and classification of Construction Waste was carried out with the monitoring of the process of receiving, registering and classifying this waste.

For classification, the waste was divided into four classes, as determined by CONAMA Resolution No. 307 (Brasil, 2002):

- Class A - these are the reusable or recyclable waste as aggregates, such as: a) construction, demolition, renovation and paving repairments and other infrastructure construction works, including soil from earthworks; b) construction, demolition, renovation and repair of buildings: ceramic components (bricks, blocks, tiles, cladding plates, etc.), grout and concrete; c) the manufacturing and / or demolition process of precast concrete parts (blocks, tubes, curbs etc.) produced at construction sites;

- Class B - these are the recyclable waste for other destinations, such as plastics, paper, cardboard, metals, glass, wood, empty packaging for home paints and plaster;

- Class $\mathrm{C}$ - these are the wastes for which no economically viable technologies or applications have been developed to allow their recycling or recovery;

- Class D -these are the hazardous wastes from the construction process, such as paints, solvents, oils and others or those contaminated or harmful to health from demolitions, renovations and repairs of radiological clinics, industrial facilities and others, as well as tiles and other objects and materials that contain asbestos or other products harmful to health.

To fill out the registration and classification form, the person in charge performed a visual check on the container, bag or lorry to determine if the load was complete or not. For full loads, the receiving volume of $5.00 \mathrm{~m}^{3}$ was determined. The person responsible for receiving carried out the classification of waste visually, identifying the volumes belonging to class $A, B, C$ and $D$.

The quantification of waste received at the company was carried out over a period of 10 months. Weekly the researcher and / or research assistants followed the receipt process, through visits to the plant with registration and data storage in an electronic spreadsheet in Microsoft Office Excel software. Subsequently, these forms were made available in an electronic spreadsheet and the data separated, in line, by date of receipt and customer, and by columns, by date, class of waste and quantity, for further study of the data obtained.

The quantification and characterization of the $\mathrm{CW}$ were essential to obtain a diagnosis of the company, and for subsequent economic, environmental and social assessment. 


\section{Phase 2 Economic evaluation of the Civil Construction Waste plant.}

\section{Phase 2.1 Evaluation by economic decision criteria}

In this phase, investments were surveyed, variable costs (raw material, electricity, fuel and water), fixed costs (labour, social charges, insurance and maintenance), administrative expenses, taxes and investments (land, buildings, equipment and working capital), carried out by the company.

Electronic spreadsheets were prepared using Excel software to analyse the investment made, including the items shown in Figure 2.

\begin{tabular}{|l|}
\hline [1] Gross revenue $=$ Price X Amount \\
\hline [2] Sales taxes $=(1) \mathrm{X} \%$ Sales taxes \\
\hline [3] Net revenue $=[1]-[2]$ \\
\hline [4] Variable Cost $=$ Unit Variable Cost X Amount \\
\hline [5] Fixed Cost \\
\hline [6] Gross Profit $=[3]-[4]-[5]$ \\
\hline [7] Variable expense $=$ Unit Variable Expense X Amount \\
\hline [8] Fixed expense \\
\hline [9] FR future fixed asset invest \\
\hline [10] Net Profit: $[6]-[7]-[8]+[9]$ \\
\hline [11] investment in fixed asset $=$ fixed asset investment \\
\hline [12] Working capital = (year 0: working capital); (year n: future value of working capital) \\
\hline FC: (year 0: $[\mathbf{1 1}]+[\mathbf{1 2}]) ;($ year 1 to n-1 [10] - [11]); (year n [10] - [11] + [12]) \\
\hline
\end{tabular}

Figure 2. Excel spreadsheet on investment analysis. Source: Authors (2017).

Figure 2 summarizes how the investment analysis was calculated and the following concepts must be understood for this:

a) Investment in Fixed Assets: composed of equipment, land, civil construction, industrial facilities, furniture, among others;

b) Gross revenue: quantity received multiplied by the price charged for receipt;

c) Sales taxes: gross revenue multiplied by the percentage of taxes on sales, such as ICMS, IPI and PIS and COFINS;

d) Net revenue: gross revenue less sales taxes;

e) Variable cost: cost related to the manufacturing process, including raw materials, packaging, freight, direct labour, consumption of electricity in the production process, industrial water and fuel;

f) Fixed cost: cost that does not depend on production, the main ones being indirect labour, equipment maintenance, insurance, water, electricity and rent;

g) Gross profit: net revenue minus variable cost and fixed cost;

h) Variable expense: sum of expenses with sales commission and financial expenses with discount of duplicates;

i) Fixed expenses: administrative expenses and fixed taxes such as IPTU and fees for permits and annual licences;

j) Residual value of the fixed asset investment: percentage referring to the fixed investment that is worth the good after its depreciation; 
k) Net income: the sum of gross profit and the future residual value of fixed asset investment, subtracting the sum of variable and fixed expenses;

I) Working capital: capital required to continue the company's financial operations, such as resources to maintain inventories and advance payment to suppliers;

To complete and comply with the investment analysis demonstrated previously, the following steps were performed:

i) Cash flow analysis, which summarized the company's income and expenses over a given period of time.

ii) Verification of the minimum attractiveness rate (TMA), to determine from which rate the investor starts to obtain financial gains.

iii) Verification of the Net Present Value Method (NPV), where the generated cash flows were analysed at present. Equation 1 was used to calculate NPV.

$$
N P V=I+\sum_{t=1}^{T} \frac{(R t-C t)}{(1+i)^{t}}
$$

Where:

NPV = Net Present Value;

$\mathrm{T}=$ Lifetime;

$\mathrm{t}=$ time, cash flow period;

$\mathrm{Rt}=$ Income over time $\mathrm{t}$;

$\mathrm{Ct}=$ Costs over time $\mathrm{t}$;

$\mathrm{I}=$ Initial investment;

$\mathrm{i}=$ Interest rate.

iv) Verification of the uniform annual worth value (AV) method, also known as the equivalent annual uniform value (EUAV) method, which consists of determining the annual uniform series (A) equivalent to the cash flow of investments at the Minimum Attractiveness Rate (MARR). Mathematically, the AV was obtained through Equation 2.

$$
A V=N P V^{*} \frac{(1+i)^{t}-1}{I^{*}(1+i)^{t}}
$$

Onde:

$\mathrm{VA}=$ Valor Anual;

NPV = Net Present Value;

$\mathrm{t}=$ time, cash flow period;

$I=$ Initial investment

v) Checking the internal rate of return (IRR). Mathematically, the IRR was obtained from the NPV formula, keeping the rate as variable and equalling the expression to zero, according to Equation 3.

$$
N P V=0=I+\sum_{t=1}^{T} \frac{(R t-C t)}{(1+I R R)^{t}}
$$


Onde:

IRR= Internal Rate of Return;

NPV = Net Present Value;

$\mathrm{T}=$ Lifetime;

$\mathrm{t}=$ time, cash flow period;

$\mathrm{Rt}=$ Incomes on time $\mathrm{t}$;

$\mathrm{Ct}=$ Costs on time $\mathrm{t}$;

I = Initial Investment;

$\mathrm{i}=$ Interest rate.

vi) Verification of the recovery method of invested capital (Payback). The discounted Payback Method consists of verifying the period of time necessary to recover the invested capital. The formulas for determining the discounted Payback are presented in Equation 4. The Payback period consists of the value of the variable $T$ that satisfies the equality expressed in Equation 4.

$$
\sum_{t=1}^{T} \frac{(R t-C t)}{(1+i)^{t}}=I
$$

Onde:

$\mathrm{T}=$ Recover time;

$\mathrm{t}=$ time, cash flow period;

$\mathrm{Rt}=$ Income on time $\mathrm{t}$;

$\mathrm{Ct}=$ Costs on time $\mathrm{t}$;

$\mathrm{I}=$ Initial investment;

$\mathrm{i}=$ Interest rate.

\section{Phase 2.2: Evaluation of the economic aspects of sustainability}

While assessing the economic aspects of sustainability, revenues and expenses from waste processing were verified. The assessment of the economic aspects of sustainability was carried out using the Global Reporting Initiative model (in which economic assessments are measured through economic performance, presence in the market and indirect economic impacts) (Global Reporting Initiative, 2007) and an assessment of economic aspects of sustainability by the model of the ETHOS Institute of Business and Social Responsibility (ETHOS) (carries out assessments regarding wealth generation, wealth distribution and productivity) (Instituto Ethos de Empresas e Responsabilidade Social, 2003).

\section{Stage 3 Evaluation of the social aspect of sustainability of the Civil Construction Waste plant.}

In this phase, a social assessment was carried out regarding labour practices. The data was provided by the company's Human Resources department. This way, the profile of employees and the profile of salaries were evaluated, a salary comparison was carried out and health and safety and education and training were evaluated.

In order to better adapt this study, adaptations were made to the model suggested by Instituto Ethos de Empresas e Responsabilidade Social (2003), and for the evaluation the type of collaborators was changed, being redefined in three categories: 
a) Women;

b) Men;

c) People over 45 years old.

This change is justified by the number of employees of the company, being concentrated in three groups of people.

Management positions were excluded from the assessment because there is no person in this position within the company.

\section{Phase 3.1 Employee profile}

In the employees' profiles, evaluations were measured over a period of one year. In addition to the three aspects used by Instituto Ethos de Empresas e Responsabilidade Social (2003), in order to complement all the functions of the company's workers, the following aspects were added:

a) Percentage in administrative positions;

b) Percentage in production positions.

\section{Phase 3.2 Wage profile}

For the wage profile, average wages were assessed and measured during the current year period, with the percentage by gender added. The methodology was adapted from Instituto Ethos de Empresas e Responsabilidade Social (2003) and considered the following indicators: average salary, percentage by gender, percentage in administrative positions, percentage in production positions.

\section{Phase 3.3 Wage comparison}

In wage comparison, evaluation was extended to all genders (women, men and people over 45 years old), this wage comparison being adapted from Instituto Ethos de Empresas e Responsabilidade Social (2003), considering the percentage in relation to the minimum wage (average wage per gender / minimum national wage) and the percentage in relation to the highest minimum wage (average wage of the gender/ the highest company wage).

\section{Phase 3.4 Health and Safety}

In health and safety, data were prepared or compiled for one year, the percentage of work accidents was added, which includes all accidents and the evaluation was extended to all genders. The health and safety assessment was carried out based on the adaptation of the Ethos method (2003), considering the following indicators: accidents in the year analysed, percentage of work accidents, percentage of work accidents with job leave, percentage of work accidents without clearance.

\section{Phase 3.5 Education and Training}

For education and training, the analysis was measured annually. The analysis seek to know the percentage of trained workers, the percentage of investment in training in 
relation to operating expenses and personnel expenses, according to the method adapted from Instituto Ethos de Empresas e Responsabilidade Social (2003). The indicators taken into consideration were: percentage of trained workers, percentage of investment in training in relation to operating costs and percentage of investment in training in relation to personnel expenses.

\section{Stage 4 Evaluation of the environmental aspect of the sustainability of the Civil Construction Waste plant}

In this phase, the benefits to the environment resulting from the implementation of a construction waste recycling plant were verified.

\section{Phase 4.1 Composition of the CW}

To check the composition of the CW, the method adapted from Rocha (2012) was used. The waste separations were carried out as determined by CONAMA Resolution 307 , classifying them in Classes A, B, C and D (Brasil, 2002).

\section{Phase 4.2 CW Separation}

After the initial quantification and classification of the $\mathrm{CW}$, the material went through a screening process, and at this stage the materials were spread on the floor, inside the shed, and separated again in the classes from CONAMA Resolution No. 307 (Brasil, 2002).

\section{Phase 4.3 How to use the CW}

After separating the CW, it was necessary to know how to use them, for this they were quantified using the method adapted from Rocha (2012).

\section{Phase 4.4 Destination of the CW}

After checking how to use the CW, it was possible to verify its destination, dividing them into three categories:

a) Product recycled by processes within the company;

b) Products sent for recycling in other companies;

c) Products destined for landfill;

\section{Results and discussion}

The results presented are in accordance with the methodological procedure and represent a set of information related to the research goal, referring to the data collected from March / 2016 to December / 2016. 


\section{Stage 1 Evaluation of the production potential of a construction waste recycling plant in Passo Fundo / RS.}

In this stage, the plant recycling process is presented, comprising the moment when the waste is received, its separation, the physical arrangement of the plant and its staff.

In 2016, there were eight companies that deposited their waste at the recycling plant. The waste is received in 3 (three) ways: metal buckets with a capacity of $5.00 \mathrm{~m}^{3}$, called tele entulho, bucket lorry with variable capacity, and through bags which are waterproof canvas containers with high volumetric capacity which are intended to be used for the transportation and storage of rubble.

When the rubble arrives at the plant, the recycling process begins. At the gate the lorries are identified and undergo a waste control where the quantity is visually checked, taking the volume of the transport source as a parameter. Afterwards, a waste receipt control form is filled in where the origin information is noted. After filling out the information, the lorry is taken to the receiving material shed, where the waste is unloaded.

In the waste separation process, the materials are placed in a hopper and sent to the recyclable selection mat, where the $\mathrm{CW}$ is sorted. After carrying out this sorting, the materials that remain on the conveyor are attracted to a magnet, located near the top of the conveyor belt, leaving, in the end, only material classified as Class A. These materials are separated by granulometry in recycled sand, pebble recycled or recycled coarse gravel.

After processing, the recycled aggregates, sand, pebble and gravel are placed in specific places to be stored and sold. The plaster is deposited in a proper place for later grinding and separation of paper and plasterboard. The product resulting from this process is deposited in an area to be sold as recycled plaster. The same occurs with wood, which after being crushed is marketed as recycled wood chips. The other materials are separated and transported to their destinations.

The physical arrangement of the process for receiving Construction Waste is distributed in order to give flow to the waste separation and manufacturing factory process. In July 2017, the physical arrangement in the company was in accordance with the layout of Figure 3.

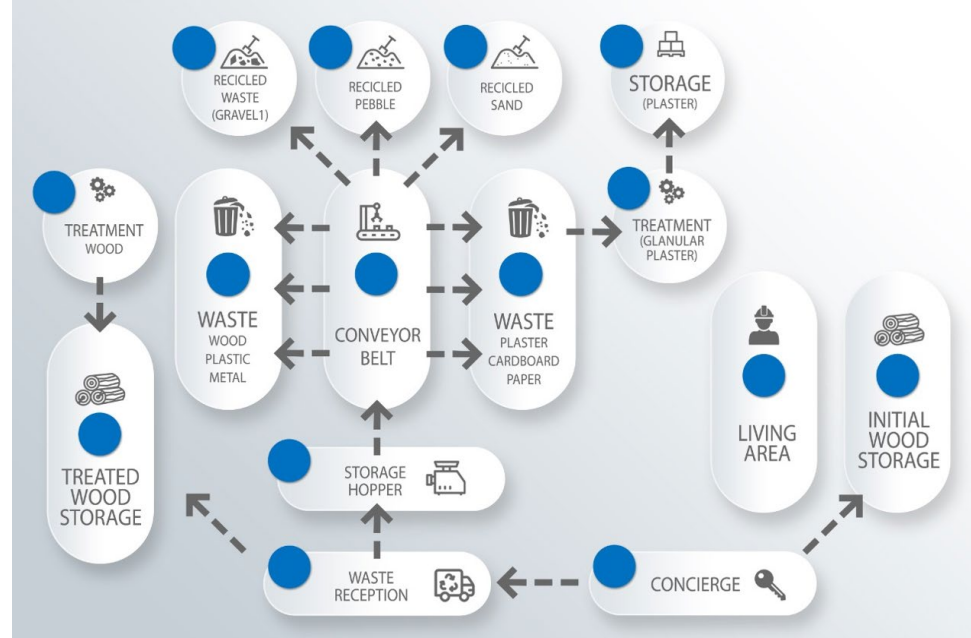

Figure 3. Physical layout of the company in July 2017. Source: Authors (2017).

The company has 12 employees. These employees are allocated in the administrative and operational process, being distributed in the office and in production as shown in Table 1 (information from March 2017). 
Table 1. Employees' amount and work departments.

\begin{tabular}{ccc}
\hline Professional & Amount & Place \\
\hline Production Assistant & 8 & Conveyor / Receipt * \\
\hline Administrative Assistant & 2 & Office \\
\hline In charge of patio & 1 & Factory patio \\
\hline Concierge & 1 & Lobby \\
\hline Total & 12 & \\
\hline
\end{tabular}

${ }^{*}$ As the conveyor belt does not operate during the entire working day, workers divide the time between the material selection tasks at the reception, patio and separation on the conveyor. Source: Authors (2017).

The labour does not need to be qualified, but all employees receive training in occupational safety and general company safety standards before starting their activities.

The material received by the company was classified according to CONAMA resolution 307 (Brasil, 2002) and the results are shown in Table 2. The data show that the plant has not received monthly, during the survey period, waste volume in the same proportion, varying over the period. The lowest volume received was $2,732.00 \mathrm{~m}^{3}$ in December 2016 and the highest volume was $6,893.50 \mathrm{~m}^{3}$ in March 2016. This difference in December is justified, since most of the city construction companies were in recess, with holiday for all the employees between Christmas and New Year.

Table 2. Quantification of waste classification by class in $2016\left(\mathrm{~m}^{3}\right)$.

\begin{tabular}{cccccc}
\hline Month & A & B & C & D & Total \\
\hline March & $3,304.30$ & $3,402.00$ & 102.20 & 85.00 & $6,893.50$ \\
\hline April & $2,176.80$ & $2,292.70$ & 105.50 & 68.00 & $4,643.00$ \\
\hline May & $2,554.50$ & $2,531.00$ & 187.00 & 37.00 & $5,309.50$ \\
\hline June & $2,110.35$ & $1,800.15$ & 132.50 & 164.00 & $4, .207 .00$ \\
\hline July & $1,935.50$ & $1,678.00$ & 116.50 & 40.00 & $3, .770 .00$ \\
\hline August & $1,995.20$ & $1,830.80$ & 44.00 & 45.00 & $3,915.00$ \\
\hline September & $2,551.50$ & $2,349.50$ & 38.00 & 80.00 & $5,019.00$ \\
\hline October & $2,060.50$ & $2,326.00$ & 8.00 & 51.00 & $4,445.50$ \\
\hline November & $2,232.50$ & $2,270.80$ & - & 10.50 & $4,513.80$ \\
\hline December & $1,196.00$ & $1,490.50$ & - & 45.50 & $2,732.00$ \\
\hline & $\mathbf{2 2 , 1 1 7 . 1 5}$ & $\mathbf{2 1 , 9 7 1 . 4 5}$ & $\mathbf{7 3 3 . 7 0}$ & $\mathbf{6 2 6 . 0 0}$ & $\mathbf{4 5 , 4 4 8 . 3 0}$ \\
\hline
\end{tabular}

Source: Authors (2017).

\section{Stage 2 Economic evaluation of the Civil Construction Waste plant.}

The evaluation by economic decision criteria sought to verify whether the company is profitable and how long the return on invested capital will be. Information was collected from the owner of the company, considering projects, environmental licensing, earthworks, infrastructure with warehouses, offices, guardhouse, three-phase energy installations, machinery and equipment and considered an amount for working capital. The total initial investment was $R \$ 1,554,030.00$.

The costs and expenses raised at the plant are related to expenses with office supplies and cleaning, water bills, electricity, internet and telephone, labour, equipment expenses and legal expenses with licences and permits, resulting in a total of $R \$ 612,297.12$ per year. In addition to the costs involved in the process, taxes that are charged must be taken into account, with the rate charged in 2016 being $10 \%$.

It is known that the entrepreneur obtains revenue from two activities: the charge for the volume of CW received and for the sale of recycled products (in 2016 the revenue obtained from the sale of recycled products was $R \$ 1,391,450.11$ ). 
To calculate the economic feasibility analysis, a period of 10 years was considered, based on most of the equipment's useful life. The Minimum Attractiveness Rate (TMA) seeks to identify the minimum that an investor proposes to earn by evaluating market rates. The TMA percentage of $8 \%$ was determined.

Based on the initial investment, the useful life and the net profit of the Plant, the Net Present Value (NPV) was calculated. The Internal Rate of Return (IRR) for the project was calculated and resulted in $15.99 \%$ a.a. being higher than TMA ( $8.00 \%$ a.a.), which indicates the economic viability of the implantation of this Plant. The return period of the project, verified through Payback, demonstrated that the invested capital will be recovered between the periods of 5 and 6 years for Simple Payback and between 6 and 7 years for Discounted Payback.

\section{Stage 3 Social assessment of the Civil Construction Waste plant.}

The assessment of social performance sought to verify the impacts of the company's activities with the internal public, suppliers, consumers / customers, the community, the government and society in general. The model adopted to evaluate this stage is the one defined by Instituto Ethos de Empresas e Responsabilidade Social (2003).

The employees' profile according to Instituto Ethos de Empresas e Responsabilidade Social (2003), seeks to separate and quantify them by gender. After collecting data at the company, it was possible to fill out the profile of the company's employees, according to Chart 1.

Chart 1. Employee profile, adapted from ETHOS (Instituto Ethos de Empresas e Responsabilidade Social, 2003).

\begin{tabular}{|c|c|c|c|c|c|c|c|}
\hline \multirow{3}{*}{ Indicator } & \multirow{3}{*}{ Categories } & \multicolumn{4}{|c|}{ Gender } & \multirow[b]{2}{*}{ Total } & \\
\hline & & Women & Men & $\begin{array}{c}\text { People } \\
\text { with } \\
\text { disabilities }\end{array}$ & $\begin{array}{l}\text { People } \\
\text { over } 45 \\
\text { years } \\
\text { old }\end{array}$ & & \\
\hline & & 2 & 9 & 0 & 2 & 13 & \\
\hline \multirow{8}{*}{$\begin{array}{l}\text { I-Employee } \\
\text { profile (current } \\
\text { year data) }\end{array}$} & \multirow{2}{*}{$\begin{array}{c}\text { Gender } \\
\text { percentage }\end{array}$} & \multirow{2}{*}{$15.38 \%$} & \multirow{2}{*}{$69.23 \%$} & \multirow{2}{*}{$0.00 \%$} & \multirow{2}{*}{$15.38 \%$} & \multirow{2}{*}{$100.00 \%$} & $\begin{array}{l}\text { Number of } \\
\text { employees by } \\
\text { gender. }\end{array}$ \\
\hline & & & & & & & $\begin{array}{l}\text { Numbers of } \\
\text { company } \\
\text { workers. }\end{array}$ \\
\hline & \multirow{2}{*}{$\begin{array}{l}\text { Percentage in } \\
\text { executive } \\
\text { positions }\end{array}$} & \multirow[b]{2}{*}{$0.00 \%$} & \multirow[b]{2}{*}{$100.00 \%$} & \multirow[b]{2}{*}{$0.00 \%$} & \multirow[b]{2}{*}{$0.00 \%$} & \multirow[b]{2}{*}{$100.00 \%$} & $\begin{array}{l}\text { Number of } \\
\text { employees by } \\
\text { gender. }\end{array}$ \\
\hline & & & & & & & $\begin{array}{c}\text { Numbers of } \\
\text { workers in } \\
\text { management } \\
\text { positions. }\end{array}$ \\
\hline & \multirow{2}{*}{$\begin{array}{l}\text { Percentage in } \\
\text { administrative } \\
\text { positions }\end{array}$} & \multirow[b]{2}{*}{$15.38 \%$} & \multirow[b]{2}{*}{$0.00 \%$} & \multirow[b]{2}{*}{$0.00 \%$} & \multirow[b]{2}{*}{$0.00 \%$} & \multirow[b]{2}{*}{$15.38 \%$} & $\begin{array}{l}\text { Number of } \\
\text { employees by } \\
\text { gender. }\end{array}$ \\
\hline & & & & & & & $\begin{array}{c}\text { Numbers of } \\
\text { workers in } \\
\text { administrative } \\
\text { positions }\end{array}$ \\
\hline & \multirow{2}{*}{$\begin{array}{l}\text { Percentage in } \\
\text { production } \\
\text { positions }\end{array}$} & \multirow[b]{2}{*}{$0.00 \%$} & \multirow[b]{2}{*}{$61.54 \%$} & \multirow[b]{2}{*}{$0.00 \%$} & \multirow[b]{2}{*}{$15.38 \%$} & \multirow[b]{2}{*}{$76.92 \%$} & $\begin{array}{l}\text { Number of } \\
\text { employees by } \\
\text { gender. }\end{array}$ \\
\hline & & & & & & & $\begin{array}{l}\text { Numbers of } \\
\text { workers in } \\
\text { production } \\
\text { positions }\end{array}$ \\
\hline
\end{tabular}

Source: Authors (2017). 
The wage profile seeks to compare the wages of workers between them and between existing positions in the company. The calculation of the average salary was $R \$ 1,516.67$ and with the results obtained, the following considerations are made:

a) Women's wages are the lowest in the company, especially in relation to the average wage, comprising $79.12 \%$ of the average wage;

b) The salary of men in production positions is $98.90 \%$ in relation to the average salary of the company;

c) Workers over the age of 45 have their average pay better than the company's average salary, resulting in rates of $125.27 \%$.

For the performance related to the salary comparison, there was a national minimum wage based on the year 2017, which was R \$937.00. This way, all company workers' salaries are higher than the national minimum wage, with the lowest percentage referring to women's salaries, $128.07 \%$, followed by the salaries of men working in production, $160.09 \%$ and people over 45 years old, which more than doubles this percentage is even higher, resulting in $207.77 \%$;

It is important for the company to recognize its performance regarding health and safety. For this, the percentages of occupational accidents in the current years are verified, as well as, which ones generate work leave, therefore are more severe. From the results obtained, the following considerations can be made:

a) The number of work accidents in 2016 was five events. These events occurred $100 \%$ with male and production workers;

b) When this number is verified in relation to the company's workers, it results that $41.67 \%$ of the workers were involved in accidents in the company;

c) Out of these accidents, $20 \%$ resulted in employee dismissal and $80 \%$ resulted in minor injuries, allowing the worker to continue the work on that day.

The company's performance in relation to education and training aims to quantify which operators received training this year, as well as, what percentages are required to invest in education and training in relation to the employees' salaries and in relation to the company's operating cost.

With the results obtained, the following considerations could be made:

a) All company employees receive training before starting their activities. These trainings consist of knowing the general safety standards of the company and the machines and equipment that exist within it. When the worker starts to operate a machine or equipment he receives specific training for the activity.

b) The percentage of investment made by the company results in $0.25 \%$ in relation to the operating cost and $0.49 \%$ in relation to the payroll.

\section{Stage 4: Environmental assessment of the Civil Construction Waste plant}

Regarding the environmental sustainability of the plant, the method adapted from Rocha (2012) was used. The waste was classified according to CONAMA Resolution 307, grouped in Classes A, B, C and D and its percentage was verified in relation to the total waste received, as shown in Chart 2. 
Chart 2. Composition of the CW by CONAMA Resolution 307.

\begin{tabular}{|c|c|c|c|c|}
\hline Indicator & Categories & $\begin{array}{c}\text { Amount } \\
\left(\mathrm{m}^{3}\right)\end{array}$ & $\begin{array}{c}\text { Percentage } \\
(\%)\end{array}$ & Gender \\
\hline \multirow{9}{*}{$\begin{array}{l}\text { I - Composition } \\
\text { of the CW by } \\
\text { CONAMA } \\
\text { Resolution } 307\end{array}$} & \multirow{2}{*}{$\begin{array}{l}\text { Percentage } \\
\text { Class A }\end{array}$} & $22,117.15$ & \multirow[t]{2}{*}{$48.66 \%$} & $\begin{array}{c}\text { Amount of Class A waste } \\
\text { divided }\end{array}$ \\
\hline & & $45, .448 .30$ & & Total waste amount \\
\hline & \multirow{2}{*}{$\begin{array}{l}\text { Percentage } \\
\text { Class B }\end{array}$} & $21,971.45$ & \multirow[t]{2}{*}{$48.34 \%$} & $\begin{array}{c}\text { Amount of Class B waste } \\
\text { divided }\end{array}$ \\
\hline & & $45,448.30$ & & Total waste amount \\
\hline & \multirow{2}{*}{$\begin{array}{l}\text { Percentage } \\
\text { Class C }\end{array}$} & 733.70 & \multirow[t]{2}{*}{$1.61 \%$} & $\begin{array}{c}\text { Amount of Class } \mathrm{C} \text { waste } \\
\text { divided }\end{array}$ \\
\hline & & $45,448 ., 30$ & & Total waste amount \\
\hline & \multirow{2}{*}{$\begin{array}{l}\text { Percentage } \\
\text { Class D }\end{array}$} & 626.00 & \multirow[t]{2}{*}{$1.38 \%$} & $\begin{array}{c}\text { Amount of Class } \mathrm{D} \text { waste } \\
\text { divided }\end{array}$ \\
\hline & & $45,448.30$ & & Total waste amount \\
\hline & Total & $45,448.30$ & $100,00 \%$ & \\
\hline
\end{tabular}

Source: Authors (2017).

The material that arrives at the factory, after quantification on receipt, is separated by type of material within the classes. This separation aims to give the appropriate destination to these materials. The separation is also performed within the classes that are in CONAMA Resolution No. 307 (Brasil, 2002).

Class A contains materials that can be reused and are separated into two types:

a) Rubble: bricks, blocks, tiles, cladding plates, mortar and concrete;

b) Soil: material from excavations and earthwork services.

Class $B$ contains materials that can be recycled for other uses, such as:

a) Wood: plywood sheets and various woods used in civil construction, pallets for storing material, eucalyptus struts;

b) Recyclable: plastic, paper, cardboard, metals, glass, empty ink packaging;

c) Plaster: plasterboard or plasterboard sheets;

d) Styrofoam: styrofoam sheets or plates.

During the waste separation it is possible to identify what can be recycled, as well as the materials destined for landfill, as is the case with materials originating from street cleaning by the City Halls, such as pruning trees, grass, branches, in addition to various dirt packed in the rubble truck.

Class $C$ waste is waste that cannot be recycled or the cost of which is impracticable, such as glass wool. These are sent to landfill.

For Class D waste such as paints, solvents, primer used in waterproofing, contaminated Class A, B or C materials or tools, a minority is sent to other recycling companies or to the manufacturers themselves (reverse logistics). However, the vast majority is sent to landfill, along with Class $C$ waste.

The way in which the $\mathrm{CW}$ is used seeks to point out the data regarding the rubble received and mainly already separated within the plant. With the data obtained through the new classification of CW the following analysis were presented:

a) The rubble to be used as recycled aggregate stands out among Class $A$ waste, with a percentage of $86.65 \%$, which corresponds to $19,164.51 \mathrm{~m}^{3}$ of material that is no longer extracted from nature and returns to the market. 
b) Still in reference to Class A waste, there are materials that although they received other classifications, such as materials that are sent to other sectors with a percentage of $3.00 \%$ and materials used in landfills or on basis for civil construction, with a percentage of $9.50 \%$, are also reused, reducing their extraction from nature, which indicates greater sustainability under the environmental aspect.

c) It is verified that $0.85 \%$ of Class A waste is sent to the landfill, after a new classification in the company, corresponding to $188.00 \mathrm{~m}^{3}$ or approximately 15 dump trucks of 12 $\mathrm{m}^{3}$ of volumetric capacity.

d) In regard to Class B waste, the use of materials is also significant, and $99.35 \%$ of the materials, after undergoing a new classification, are able to be recycled and thus return to the market. The rest, $0.65 \%$ of these materials are destined for landfill.

e) Class $\mathrm{C}$ waste, as it is difficult to recycle, has its percentage of materials destined for landfill with a percentage of $80 \%$, although they represent $586.96 \mathrm{~m}^{3}$ of rubble or 49 dump trucks with $12 \mathrm{~m}^{3}$ of volumetric capacity. The remaining $20 \%$ of Class $\mathrm{C}$, after a new classification, are possible to be recycled.

f) Class D waste, as it is hazardous material, is in its entirety sent to specialized companies.

Regarding the destination of the CW, waste can be grouped with the same destination, classifying their destinations as: a) Recycled product; b) Recycling companies; c) Landfill. In this way, the results shown in Figure 4 were obtained.

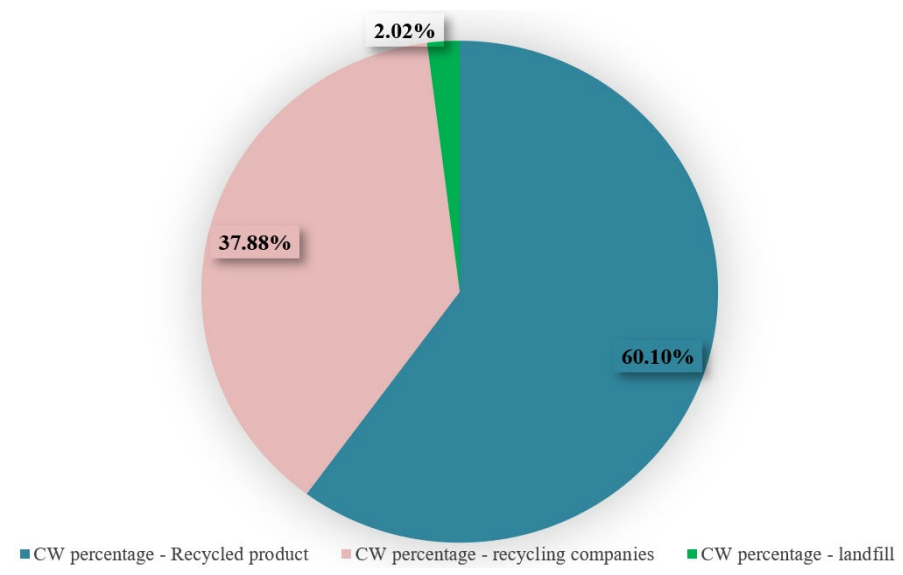

Figure 4. CW destination. Source: Authors (2017).

With the evaluation of $\mathrm{CW}$ usage, it was possible to verify the destination of the waste, with $97.98 \%$ of the waste that is received by the recycling company being able to be used again in the market, both as recycled products $(60.10 \%)$ or those sent to recycling companies $(37.88 \%)$. Out of the total waste received, $2.02 \%$ of these are sent to landfills, which corresponds to $917.77 \mathrm{~m}^{3}$ / year. These results demonstrate the great potential for reuse and recycling of $\mathrm{CW}$, causing the by-products (which until then were considered to be waste) to be reinserted in the life cycle of new products, promoting environmental sustainability. 


\section{Final considerations}

During data collection, it was possible to partially monitor the receipt of waste, and the data collected allowed us to verify that the plant received $45,448.30 \mathrm{~m}^{3}$ of rubble in the period from March to December 2016, the equivalent of $4,548.83 \mathrm{~m}^{3}$ of rubble per month, with Class $A$ and $B$ residues predominating.

The economic evaluation carried out based on the economic decision criteria shows that the company is profitable, considering a Minimum Attractiveness Rate of $8 \%$ a.a., as the results show that the IRR, calculated at $15.99 \%$, is higher than the TMA. Thus, it is concluded that the company is economically viable, serving as an example for new feasibility studies for setting up companies in other municipalities.

The evaluation on the social aspect of sustainability of the civil construction waste plant verified the profile of the company's workers, noting that $30.76 \%$ of these are women and men over 45 years old. The wage profile showed that workers over the age of 45 have their average salary $25.27 \%$ higher than the company average salary. In this point, women have the lowest salaries in the company, in the order of $79.12 \%$ of the average salary of employees.

All company workers' wages are higher than the national minimum wage, with the lowest percentage referring to women's wages, $128.07 \%$, followed by the wages of men working in production, $160.09 \%$ and those above 45 years is $207.77 \%$.

In terms of social performance related to health and safety, women and men over 45 were not involved in occupational accidents, and male employees under the age of 45 were involved in these accidents. It should be noted that these employees are the ones directly linked to production. The percentage of employees involved in an accident at work was $41.67 \%$ in relation to the number of workers and that $80.00 \%$ of these accidents did not require employees leave.

Thus, from a social point of view, the company generates jobs and, at the same time, with better remuneration than the national minimum wage. Besides that, promoting job opportunities for men and women and workers over 45 years of age.

Regarding the evaluation of the environmental aspect of the sustainability of the CW plant, it was found that Class A (bricks, blocks, mortar, demolition debris, among others) and Class B (wood, plaster, plastic paper, among others) waste arriving at the plant are predominant compared to the total waste processed.

Under the environmental aspect, the $\mathrm{CW}$ recycling company has the capacity to reuse $97.98 \%$ of the material received, and the Class A contribution is $48.66 \%$ or approximately $22,117 \mathrm{~m}^{3}$ of materials that are no longer extracted from nature and can be recycled and used as aggregates in civil construction, thus contributing to environmental sustainability.

Thus, the present work demonstrates that the $\mathrm{CW}$ plant is an enterprise that promotes sustainability, bringing several environmental and social benefits, in addition to being economically viable.

\section{References}

Almeida, J., Rosa, F. D., Pandolfo, A., Berticelli, R., Brum, E. M., \& Martins, M. S. (2018). Estudo de viabilidade econômica do uso do agregado de RCD em pavimentação de vias urbanas. Revista de Engenharia Civil, 54, 16-25.

Baptista, J. V., Jr., \& Romanel, C. (2013). Sustentabilidade na indústria da construção: uma logística para reciclagem dos resíduos de pequenas obras. Urbe. Revista Brasileira de Gestão Urbana, 5(2), 27-37. http://dx.doi.org/10.7213/urbe.05.002.SE02.

Barbosa, J. (2012). Destinação dos resíduos sólidos de construção e demolição do Município de Passo Fundo- RS: Desafios e Perspectivas (Tese de graduação). Universidade de Passo Fundo, Rio Grande do Sul. 63 p. 
Bohne, R. A., Brattebø, H., \& Bergsdal, H. (2009). Dynamic eco-efficient projections for construction and demolition waste recycling strategies at the city level. Journal of Industrial Ecology, 12(1), 52-60. http://dx.doi.org/10.1111/j.1530-9290.2008.00013.x.

Brasil. (2010, 2 de agosto). Lei $n^{\circ} 12.305$ de 2 de Agosto de 2010. Institui a Política Nacional de Resíduos Sólidos, altera a Lei n 9.605, de 12 de fevereiro de 1998 e dá outras providências. Brasília, DF: Diário Oficial da República Federativa do Brasil. Retrieved in 2016, September 10, from http://www.planalto.gov.br/ccivil_03/_ato2007-2010/2010/lei//12305.htm

Brasil. Ministério do Meio Ambiente. Conselho Nacional do Meio Ambiente (2002, 5 de julho). Resolução $n^{\circ} 307$, de 05 de julho de 2002. Alterada pelas Resoluções $n^{\circ} 348$, de 2004, $n^{\circ}$ 431, de 2011 e $n^{\circ}$ 448, de 2012. Dispõe sobre gestão dos Resíduos da Construção Civil. Brasília, DF: Diário Oficial da República Federativa do Brasil. Retrieved on 2016, September 3, from http://www.mma.gov.br/port/conama/legiabre. cfm?codlegi=307

Global Reporting Initiative (2007) - Sustainability Reporting Guidelines on Economic, Environmental and Social Performance - Global Reporting Initiative. Amsterdam. 51 p. Retrieved in 2016, September, 12, from http://www.esbnetvaerk.dk/images/pdf/deloitte\%20g3_guidelinesenu.pdf.

Halmeman, M. C. R., Souza, P. C., \& Casarin, A. N. (2009). Caracterização dos resíduos de construção e demolição na unidade de recebimento de resíduos sólidos no município de Campo Mourão - PR. Revista Tecnológica. Edição Especial ENTECA, 2009, 203-209.

Instituto Ethos de Empresas e Responsabilidade Social. (2003). Guia de Elaboração do Balanço Social. São Paulo: ETHOS.

John, V. M. (2000). Reciclagem de resíduos na construção civil: contribuição à metodologia de pesquisa e desenvolvimento (Tese - Livre-Docência em Engenharia Civil). Escola Politécnica, Universidade de São Paulo, São Paulo, Brasil. 120 p.

Miranda, L. F. R., Levi, T., Vogt, V., Brocardo, F. L. M., \& Bartoli, H. (2016). Panorama atual do setor de reciclagem de resíduos de construção e demolição no Brasil. In Anais do XVI Encontro Nacional de Tecnologia do Ambiente Construído. São Paulo/SP: ENTAC.

Moraes, N. C., \& Henkes, J. A. (2013). Avaliação do programa de gerenciamento de resíduos da construção civil e demolição, no município de Caçapava-SP. Revista Gestão \& Sustentabilidade Ambiental, 2(1), 113-134. http://dx.doi.org/10.19177/rgsa.v2e12013113-134.

Paschoalin, J. A., Fo. \& Duarte, E. B. L. (2015). Caracterização e destinação dos resíduos de construção gerados a construção de um edifício comercial localizado na cidade de São Paulo. Revista Gestão \& Sustentabilidade Ambiental, 3(2), 223-246. http://dx.doi.org/10.19177/rgsa.v3e22014223-246.

Passo Fundo (2013, 03 de janeiro). Lei $n^{\circ} 4.969$, de 03 de janeiro de 2013. Institui a Política Municipal de Resíduos Sólidos de Passo Fundo e dá outras providências. Retrieved on August, 10th 2016, from http://pmpf.rs.gov.br/index.php?p=1145\&a=1\&pm=1\&ifr=1.

Passo Fundo. Prefeitura Municipal. (2016). Fundação Passo Fundo/RS de Turismo. Retrieved on October, 2nd 2016, de http://www.pmpf.rs.gov.br/secao.php?t=11\&p=325

Pinto, T. P., \& Gonzáles, J. L. R. (2005). Manejo e gestão dos resíduos da construção civil. Volume 1 - Manual de orientação: como implementar um sistema de manejo e gestão nos municípios. Brasília: CAIXA. 194 p.

Rocha, M. P. (2012). Proposta de indicadores de sustentabilidade na gestão de resíduos de construção e demolição (Dissertação de mestrado). Departamento de Engenharia Civil, Faculdade de Engenharia da Universidade do Porto, Porto, Portugal.

Silva, V. A., \& Teixeira Fernandes, A. L. (2012). Cenário do gerenciamento dos resíduos da construção e demolição (RCD) em Uberaba-MG. Sociedade \& Natureza, 24(2), 333-334.

Zanutto, T. D. (2012). Diagnóstico para subsidiar a gestão de resíduos da construção civil na cidade de São Carlos - SP (Dissertação de mestrado). Programa de Pós-graduação em Engenharia Civil, Universidade de São Carlos, São Carlos, Brasil. . 